\title{
Influence of solar activity on global large rivers runoff trends
}

\section{BAKHRAM NURTAEV}

Solterra Science, Kapfenbergerstr.17, Frechen, D-50226 Germany nurtaev@gmx.net

\section{INTRODUCTION}

The physical basis of the influence of solar activity on the climate is evident. The sun's heat and light energy warms the land surface and oceans and they radiate heat back into the air above. It is believed that increase of solar activity leads to a rise in atmospheric temperature, intensification of the hydrological cycle and consequently to an increase in river flow. The impacts of climate change have led to an increase in global and continental runoff in the last century (Labat et al. 2004). Observations also show a long-term increase trend of solar activity over the period 1855-1996 (Krivova and Solanki 2004). This phenomenon initiated a project to test the hypothesis: influence of solar activity on rivers discharge.

\section{SOLAR ACTIVITY AND RIVERS DISCHARGE}

We investigated six large rivers with observation periods of over 70 years located in different regions of the Earth. The Earth's rotation on its axis and solar energy cause prevailing wind patterns, such as the Westerlies and Trade Winds. The direction of the prevailing wind affects the mass transfer of water vapour from main source of water, the oceans. In this way geomorphology plays an important role for water formation processes (e.g. mountain ranges as natural barriers to wind intrusion and clouds).

An analysis of river formation regularities is compounded by the fact that the rivers' connectivity and flow regime have been altered over a long period by dams and reservoirs. Volcanic activity also contributes to significant climate and river formation changes. There is a significant positive relationship between solar activity and the Rhine River (Köln) runoff over the period of 1855-1996:

$$
\mathrm{Q}(\text { Rhine })=0.22 \mathrm{~W}+55.19 \quad \mathrm{r}=0.83
$$

where $\mathrm{Q}$ is river discharge $\left(\mathrm{km}^{3} / \mathrm{year}\right), \mathrm{W}$ is the number of sunspots, and $\mathrm{r}$ is the coefficient of correlation.

At the same time, for the Danube River (Nagymaros), a steady decreasing trend of river runoff with dependence on solar activity, over the period of 1890-1996 is observed:

$$
\mathrm{Q}(\text { Danube })=-0.11 \mathrm{~W}+78.74 \quad \mathrm{r}=0.76
$$

This phenomenon can be explained because the prevailing wind delivers more intense rains in the Rhine watershed and, relatively, a low amount of precipitation reaches the Danube River basin.

The empirical relationship between solar activity and the Songhua Jiang River over the period 1902-1996 can be described as:

$$
\mathrm{Q}(\text { Songhua Jiang) }=0.28 \mathrm{~W}+22.62 \quad \mathrm{r}=0.76
$$

The empirical relationship between discharge of the Mississippi River and solar activity over the period of 1890-2008 can be written:

$$
\mathrm{Q}(\text { Mississippi })=0.87 \mathrm{~W}+125.9 \quad \mathrm{r}=0.82
$$

The empirical relationship between discharge of the Amur River and solar activity over the period of 1902-1996 has a negative trend:

$$
\mathrm{Q}(\text { Amur })=-0.95 \mathrm{~W}+297.3 \quad \mathrm{r}=0.85
$$

The same negative trend was calculated for the relationship between discharge of the Yangtze River over the period of 1878-1986 and solar activity: 


$$
\mathrm{Q}(\text { Yangtze })=-1.36 \mathrm{~W}+790.5 \quad \mathrm{r}=0.72
$$

The dynamics of water inflow into the World Ocean shows dependence on solar activity over the period 1923-1986, and highlights a stable increasing trend of global inflow to the oceans (Shiklomanov 2000).

$$
\mathrm{Q}(\text { Global })=15.18 \mathrm{~W}+40274 \quad \mathrm{r}=0.83
$$

\section{DISCUSSION}

The study shows that the solar activity affects on hydrological process are different for rivers in diverse geographical locations. The positive relationship between solar activity and river runoff is actually conventional. An increase of solar activity has to actually increase the large rivers discharge. Intensification of atmospheric circulation due to climate change makes the water cycle more intensive. Thus, orography plays a crucial role in a change in atmospheric conditions caused by a change in elevation, primarily due to mountains. The mountain ranges intercept a mass transfer of evaporated water. The climate on the leeward side of a mountain differs from that on the windward side mostly in the amount of rainfall. In accordance with NASA forecasting, the solar cycles 24 and 25 will be very weak, and that will lead to following: the global temperatures will be trending lower over the next 20 years. Rivers discharge will be change in dependence from geographical location.

Acknowledgements The source of the data: The Global Runoff Data Centre (GRDC), Koblenz, Germany.

\section{REFERENCES}

Krivova, N.A. and Solanki, S.K. (2004) Solar variability and global warming: a statistical comparison since 1850. Advances in Space Research 34, 361-364.

Labat, D., et al. (2004) Evidence for global runoff increase related to climate warming. Advances in Water Resources 27(6), 631-642.

Shiklomanov, I. (2000) International Hydrological Programme (IHP) of UNESCO. http://webworld.unesco.org/water/ihp/db/shiklomanov 